\title{
COMPARATIVE STUDIES ON THE LEVELS OF VITAMINS DURING VERMICOMPOSTING OF FRUIT WASTES BY EUDRILUS EUGENIAE AND EISENIA FETIDA
}

\author{
${ }^{I}$ Ph.D Research Scholars in Biochemistry, \\ ${ }^{2}$ Reader in Biochemistry \\ ${ }^{3}$ Reader in Zoology \\ Kongunadu Arts and Science College, \\ Coimbatore - 641 029, Tamil Nadu, India. \\ e-mail: jeyaraaj_indira@yahoo.co.in \\ (Received $6^{\text {th }}$ March 2006 ; accepted $13^{\text {th }}$ May 2007)
}

${ }^{1}$ M. LAKShMi PrabHa, ${ }^{2}$ Indira A. JAYRAaJ, ${ }^{3}$ JeyARAAJ, R AND ${ }^{1}$ SRINIVASA RAO .D.

\begin{abstract}
Organic wastes are extensively increasing with increased human populations, intensive agriculture and industrialization. The disposal of wastes has become important for a healthy quality of environment. In this regard recycling of utilizable organic wastes is feasible. The recycling of wastes through vermicomposting reduces problems of disposal of organic wastes. Vermicomposting, a novel technique of converting decomposable organic wastes into valuable vermicompost through earthworm activity is a faster and better process when compared with the conventional methods of composting. Within a very short period, a good quality compost rich in nutrient and vitamins is prepared, which is a highly efficient, cost effective and ecologically sound input for agriculture. The present study was carried out to find the changes in the levels of vitamins namely vitamin $\mathrm{A}$, vitamin $\mathrm{E}$ and vitamin $\mathrm{C}$ present in fruit wastes during vermicomposting at different time intervals (15, 30 and 45 days) by Eudrilus eugeniae and Eiseniae fetida. The levels of vitamin A, E, and C were found to be higher in fruit wastes degraded by Eisenia fetida than Eudrilus eugeniae.
\end{abstract}

Keywords: Vermicomposting , fruit wastes, Eudrilus eugeniae, Eisenia fetida, Vitamins.

\section{Introduction}

Waste is the spoilage, loss or destruction of either matter or energy, which is unusable to man. Gradually increasing civilization through industrialization and urbanization has led to increase in the generation of wastes polluting environment from various sources. The fruit wastes generated in market yards, hostels, hotels and houses are dumped into an open land. This process not only reduces the available fertile land, which was used to produce food and raw materials, but also pollutes air, water and soil. To overcome this problem wastes can be used to produce valuable organic manure by using vermitechnology ${ }^{1}$.

Vermitechnology is an important aspect of biotechnology involving the use of earthworms for processing various types of organic wastes into valuable resources. Vermicomposting helps to process wastes simultaneously giving biofertilizers and proteins ${ }^{2}$. Thus vermitechnology could successfully be used to clean the environment as it uses wastes as raw material to change polluted, costly chemical farming to sustainable agriculture ${ }^{3}$.

Soil animals are important contributors to soil fertility and humification processes. Of which, earthworms should be considered as key-stone organisms in regulating nutrient cycling processes in many eco-systems4. Earthworms can consume practically all kinds of organic wastes, consume two to five times its body weight and after using 5 
- 10 percent of the feed stock for its growth, excrete mucus coated undigested matter as nutrients and vitamins rich worm casts ${ }^{5}$. Vermicasts are a resource that are rich in mineral nutrients, vitamins, plant growth hormones, proteins and enzymes. Thus vermicast is considered as a very good organic fertilizer and soil conditioner. Hence the present study was carried out to find the changes in the levels of vitamin $\mathrm{A}, \mathrm{E}$ and $\mathrm{C}$ in fruit wastes during vermicomposting at different time intervals (15, 30 and 45 days) by Eudrilus eugeniae and Eisenia fetida.

\section{Experiment}

\section{Collection and predecomposition of fruit waste}

The fruit wastes were collected from Annamalai fruit stall, State Bank of India Road, Coimbatore - 641 018, Tamil Nadu, India and in Pazhamudir Nilayam, Nehru stadium, Coimbatore - 641 018, Tamil Nadu, India . The collected fruit wastes were chopped into small pieces and allowed to partial decomposition for 20 days. Then the wastes were mixed with cowdung in 3:1 ratio and used for vermicomposting.

\section{Collection and Culturing of earthworms}

The epigeic earthworms Eudrilus eugeniae and Eisenia fetida were collected from Aarthi farms, Kondegoundampalayam village, Pollachi Taluk, Coimbatore, Tamilnadu. The species were cultured at Kongunadu Arts and Science College, Coimbatore, Tamilnadu, India premises for six months.

\section{Vermicomposting of fruit wastes}

Pits of $0.75 \times 0.75 \times 0.75 \mathrm{~m}$ size were dug and floor of the pit was covered with the lattice of wood strips to provide drainage. Totally seven pits were maintained for experimental purposes. The pit $\mathrm{T}_{1}$ was maintained as control for fruit wastes (without earthworm), $T_{2}, T_{3}, T_{4}, T_{5}, T_{6}$ and $T_{7}$ (with earthworm) were taken for composting of fruit wastes. In each pit a total of $60 \mathrm{~kg}$ of fruit wastes were taken and in $T_{2}, T_{3}$ and $T_{4}$ pits the earthworm Eudrilus eugeniae and in $\mathrm{T}_{5}, \mathrm{~T}_{6}$, and $\mathrm{T}_{7}$ pits the earthworm Eisenia fetida were released on the surface at the rate of 60 worms per square feet except control. Care was taken to avoid light, rainfall and natural enemies. In control as well as experimental pits, the compost samples were taken on the $15^{\text {th }}, 30^{\text {th }}$ and $45^{\text {th }}$ days for the analysis of vitamins.

Vitamin A was assayed by the method of Nield and Pearson $(1963)^{6}$, vitamin E by the method described by Varley et al., $(1980)^{7}$ and $\mathrm{C}$ by the method described by Sadasivam and Balasubramaniam (1987) ${ }^{8}$.

\section{Statistical Analysis}

For the purpose of statistical analysis, Duncan's multiple range test was applied for comparing the levels of vitamins at different time intervals. 


\section{Results and Discussion}

Selection of earthworm species is very important factor because only few species are able to survive and adjust to a particular type of environment. Eudrilus eugeniae and Eisenia fetida can be cultured very well on fruit wastes. These species were selected and tested for biodegradation of fruit wastes. Eudrilus eugeniae a tropical earthworm commonly called African night crawler, is large in size, grows rapidly, breeds fast and is capable of decomposing large quantities of organic materials into usable vermicompost. Eisenia fetida popularly known as European worm or Tiger worm is ubiquitous and many organic wastes became colonized naturally by this species. They have a wide temperature tolerance and can live in organic wastes within a wide range of moisture content. ${ }^{9}$ The levels of various vitamins namely Vitamin $\mathrm{A}, \mathrm{E}$ and $\mathrm{C}$ in fruit wastes degraded by Eudrilus eugeniae and Eisenia fetida at different time intervals (15, 30 and 45 days) are depicted in Table 1 and Figure 1, 2 and 3 respectively.

Table 1. The level of vitamin A, vitamin $E$ and vitamin $C$ in the fruit wastes during different time intervals (15,30and 45 days) of composting by Eudrilus eugeniae and Eisenia fetida.

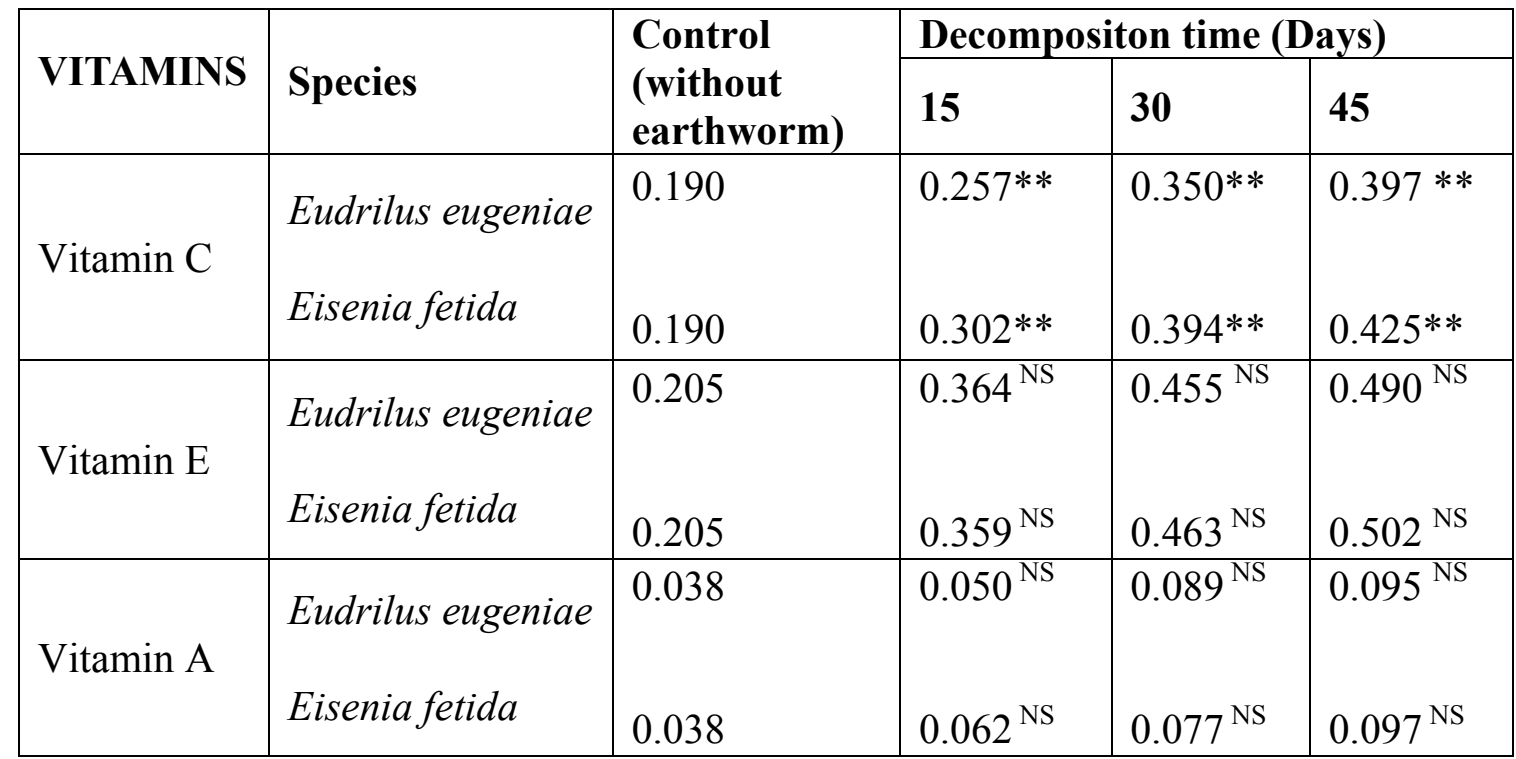

$* * \mathrm{P}<0.01$

NS - Non significant

\section{Units:}

Vitamin C - unit - $\mu \mathrm{g} / \mathrm{g}$

Vitamin E - unit - $\mu \mathrm{g} / \mathrm{g}$

Vitamin A - unit - $\mu \mathrm{g} / \mathrm{g}$

The level of vitamin A, E and $\mathrm{C}$ were found to be increased significantly and reached the maximum on the $45^{\text {th }}$ day of composting by Eudrilus eugeniae and Eisenia fetida. The level of vitamin $C$ was found to be significantly increased at $1 \%$ on the $15^{\text {th }}, 30^{\text {th }}$ and $45^{\text {th }}$ days of composting by Eudrilus eugeniae and Eisenia fetida when compared to control. 
Figure 1. Represents the level of vitamin $A, E$ and $C$
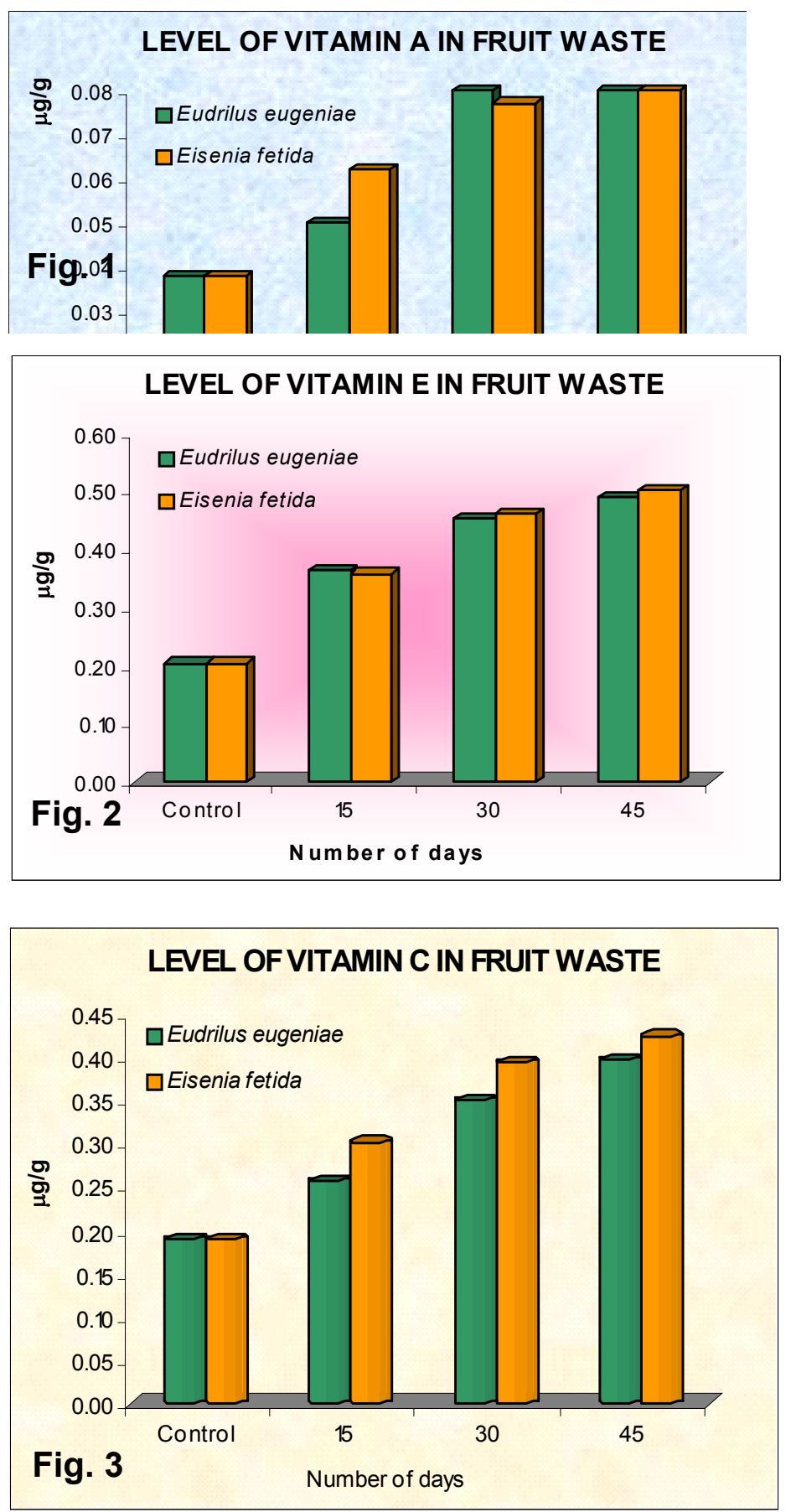

Fruits are rich source of vitamin A, E and C. When the earthworms feed on the vitamins rich fruit wastes, they excrete mucus coated undigested matter as worm casts, rich in nutrient and vitamins. Between the two species selected for the study more levels of vitamin $\mathrm{A}, \mathrm{E}$ and $\mathrm{C}$ were found in the fruit wastes degraded by Eisenia fetida as compared to Eudrilus eugeniae. As a conclusion, vermicompost can be considered as nutritionally superior as other kinds of organic manures. 


\section{REFERENCES}

[1] U. Padma, R.S Rao, and N. Srinivas, (2002): Eco-friendly disposal of vegetable wastes through vermitechnology. - J. Ecobiol. 14, 155-159.

[2] L.M., Prabha, I.A. Jayraaj and R Jeyaraaj, (2005): Macro and Micronutrient changes in vermicomposting of vegetable wastes using Eudrilus eugeniae. - South Asian Journal of Socio-Political Studies, 2, 129-130, 156.

[3] O.P., Lal, Y.N Srivastava, and S.R. Sinha (2003): Vermicomposting. - Indian Farming, $526-8$.

[4] G. Tripathi and P. Bhardwaj (2004): Comparative studies on biomass production, life cycles and composting efficiency of Eisenia fetida (Savigny) and Lampito mauritii (Kinberg). - Bioresource Technology. 92, 275-283.

[5] S.A., Ismail, P. Joshi and A. Grace. (2004): The waste in your dust bin is scaring the environment- the biotechnology of composing. - Advanced Biotech, 2, 30-34.

[6] Neild and Pearson, C.A. Burtis and A. Ashwood, (1963): Text book of clinical Chemistry, $27: 1280-1282$.

[7] H. Varley, A. Gowentock and M. Bell (1980): Practical clinical Biochemistry. Vol. I. William Heinemann Medical Book Ltd, London.

[8] S. Sadasivam and Theymoli Balasubramanian (1987): Practical manual in Bio-chemistry. TNAU Coimbatore p17.

[9] A.K., Mall, A. Dubey and S. Prasad (2005): Vermicompost: An inevitable tool of organic farming for sustainable agriculture. - Agrobios Newsletter, 3, 10-11. 